\title{
Reduced inorganic sulfur in sediments of the mariculture region of Sanggou Bay, China
}

\author{
Xuming Kang ${ }^{1}$, Sumei Liu ${ }^{1,2, *}$, Xiaoyan Ning ${ }^{1}$ \\ ${ }^{1}$ Key Laboratory of Marine Chemistry Theory and Technology MOE, Ocean University of China/ \\ Qingdao Collaborative Innovation Center of Marine Science and Technology, Qingdao 266100, PR China \\ ${ }^{2}$ Laboratory of Marine Ecology and Environmental Science, \\ Qingdao National Laboratory for Marine Science and Technology, Qingdao, PR China
}

\begin{abstract}
Reduced inorganic sulfur (RIS) and organic matter (OM) in a mariculture region (Sanggou Bay, China; SGB) and at a reference station without mariculture were determined to assess the influence of mariculture on sulfide accumulation and the benthic environment. To this end, sediment acid-volatile sulfide (AVS), pyrite sulfur (pyrite-S), elemental sulfur (ES), OM, porosity, reactive iron, and pore water sulfate were measured. The results indicate that the concentration of RIS was negatively correlated with dissolved oxygen concentration. Principal component analysis showed that sulfide distribution was influenced by sediment porosity, OM, and reactive iron concentration. In addition, sulfide distribution was influenced by water current and water depth. More sulfide content accumulated at an oyster monoculture site than at a scallop/ kelp polyculture site and a kelp monoculture site. We found no significant difference in ES concentration among the 3 mariculture types. While no significant influence on benthic OM accumulation was observed, except slightly enhanced reactivity of the OM (making it easily decomposable), mariculture activities in SGB significantly promoted sulfide accumulation compared to the reference station. However, there was no potential threat of toxic sulfide to the benthic biomass in SGB.
\end{abstract}

KEY WORDS: Acid volatile sulfide $\cdot$ Pyrite-S · Elemental sulfur - Sediment · Mariculture · Sanggou Bay

\section{INTRODUCTION}

World aquaculture output increased continuously from 1950 to 2011, and now accounts for $41.3 \%$ of the global supply of fish, crustaceans, and mollusks (FAO 2012). However, despite improved production efficiency, scallop and oyster mariculture generates massive quantities of biological deposits enriched with organic matter (OM) (Carlsson et al. 2009). The accumulation of these organic-rich deposits in sediments of mariculture regions stimulates benthic mineralization and oxygen depletion (Carlsson et al. 2009), and consequently promotes dissimilatory sulfate reduction. Major environmental and ecological

\footnotetext{
*Corresponding author: sumeiliu@ouc.edu.cn
}

issues arising from sulfate reduction include the accumulation of toxic sulfide (e.g. $\mathrm{H}_{2} \mathrm{~S}$ ), acid-volatile sulfide (AVS), pyrite sulfide (pyrite-S), and elemental sulfur (ES) in the impacted sediments (Otero et al. 2006, Gao et al. 2013) and nutrient release to the overlying water (Hyun et al. 2013). The toxic sulfide can threaten benthic macrofauna and its diversity (Yokoyama 2003). Moreover, the dissolved sulfide in sediments is highly reactive and is rapidly reoxidized by oxygen, nitrate, or oxidized Fe and $\mathrm{Mn}$, resulting in the deterioration of anoxic conditions. In addition, studies of reduced inorganic sulfur (RIS, e.g. AVS, pyrite-S, and ES) in sediments can contribute to better understanding of benthic miner-

() The authors 2016. Open Access under Creative Commons by Attribution Licence. Use, distribution and reproduction are unrestricted. Authors and original publication must be credited. 


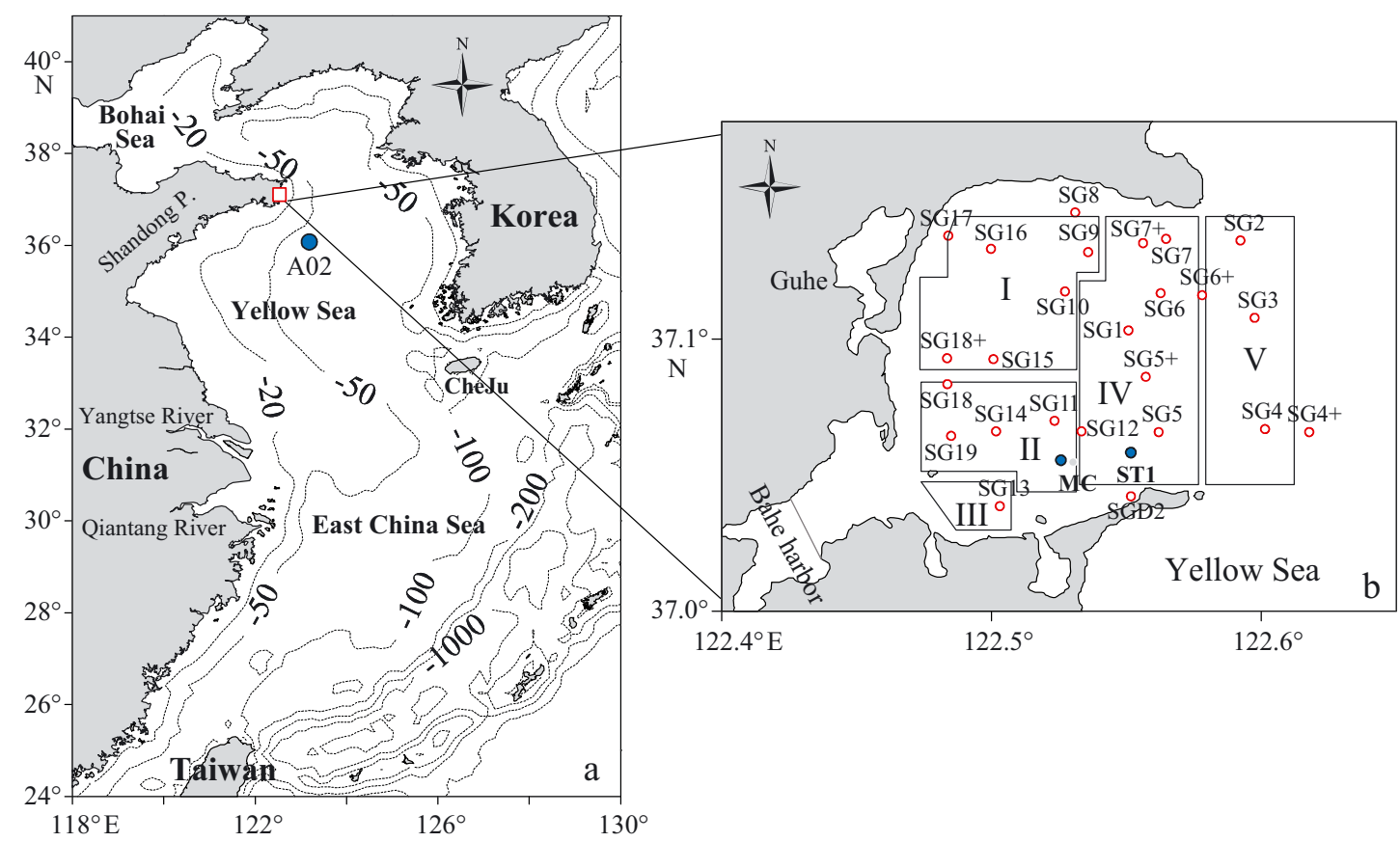

Fig. 1. Study area. (a) East China marginal seas and the location of Sanggou Bay (SGB, inside the red rectangle). (b) Mariculture areas and sampling stations in SGB. (I) scallop monoculture, (II) oyster monoculture, (III) fish monoculture, (IV) scallop/ kelp polyculture, and (V) kelp monoculture. Filled circles represent core sediment sampling stations, and open circles represent surface sediment sampling stations

alization processes related to sulfate reduction, the impacts of sulfate reduction on other element cycles (e.g. $\mathrm{N}$ and $\mathrm{P}$ cycles), and the biogeochemical behavior of trace elements in marine ecosystems (HuertaDiaz et al. 1998, Lückge et al. 1999, Burton et al. 2006). Therefore, extensive studies related to sulfide, especially the RIS in sediments, have been conducted worldwide, including in mariculture regions (Yokoyama 2003, Holmkvist et al. 2011, Gao et al. 2013, Hyun et al. 2013, Kraal et al. 2013, Zhu et al. 2013).

Environmental responses of Sanggou Bay (SGB), Shandong Province, China, to mariculture have received more attention in recent years (Zhang et al. 2009), including nutrient conditions and benthic nutrient fluxes (Sun et al. 2010, Ning et al. 2016, this Theme Section), natural sedimentation (Cai et al. 2003), and phytoplankton (Lu et al. 2015). However, reports about the impact of mariculture on benthic biogeochemistry, especially sulfur chemistry in SGB, still remains poor. Considering that the concentration and distribution of RIS species are strongly influenced by OM inputs and thus by mariculture, high concentrations of AVS, pyrite-S, and ES in sediments receiving high $\mathrm{OM}$ inputs may be well coupled to each other, and the spatial coupling may be used to trace mariculture influence. To test this hypothesis, we quantified RIS and OM characteristics in sediments of SGB and analyzed their spatial patterns. The spatial patterns were then used to trace potential mariculture impacts on sediment biogeochemistry and the benthic environment of the bay. Other factors influencing sulfide distributions were also addressed in this work.

\section{MATERIALS AND METHODS}

\section{Study site}

SGB, a semi-enclosed bay located in the western Yellow Sea (YS) (Fig. 1a), occupies a total area of approximately $144 \mathrm{~km}^{2}$ and has a mean depth of $7.5 \mathrm{~m}$. SGB is the most important integrated multitrophic aquaculture location in northern China. Suspended multi-species aquaculture of Farrer's scallop Chlamys farreri, Pacific oyster Crassostrea gigas, and kombu kelp Saccharina japonica is well developed in SGB, occupying almost $67 \%$ of the total aquaculture area (Zhang et al. 2009), and annually supplies 15000 and $84500 \mathrm{t}$ of scallop and kelp, respectively. Three mariculture models for scallop and kelp are currently employed in SGB, viz. monoculture of scallop, monoculture of kelp, 
and polyculture of scallop/kelp. The scallop-dominant polyculture system was implemented to maximise economic gains from aquaculture. The culture ratio for scallop and kelp is 2:1, and details of the maricultural facilities can be found in Fang et al. (1996). Mariculture densities for scallop and kelp are reduced to $2 / 3$ and $2 / 5$ compared to their monoculture densities, respectively. Biodeposition rates have increased rapidly along with the expansion of maricultural activities, and can be up to $278.8 \mathrm{~g} \mathrm{~m}^{-2} \mathrm{~d}^{-1}$ (Cai et al. 2003). In integrated multi-trophic aquaculture systems, kelp assimilates nutrients and $\mathrm{CO}_{2}$, converting them into potentially valuable biomass. Scallop cultivation can stimulate carbon migration from the water column to the sediment through filter-feeding and biodeposition (Chopin et al. 2008). Thus, SGB provides an excellent opportunity to investigate the influence of integrated multi-trophic aquaculture systems on RIS in sediments.

\section{Sampling}

Field expeditions aboard the RV 'Lurong Fisher 65580' were conducted during April 2013 in SGB. To elucidate the impacts of mariculture on RIS accumulation, 27 surface and 2 core sediments in different mariculture regions were sampled using a box corer (Fig. 1b), and a station without mariculture in the YS from Kang et al. (2014) was selected as a reference station (Stn A02; Fig. 1a). The physico-chemical characteristics were fairly similar between SGB and the YS. Previous studies showed that the nutrient conditions (Sun et al. 2010), OM and biogenic elements (e.g. matrix-bound phosphine) (Li et al. 2010), and total organic carbon (TOC) concentrations in sediment and benthic effluxes in SGB (Ning et al. 2016) are comparable to those in the YS. During the sampling process, each sediment core was sectioned on board in a nitrogen atmosphere (to prevent oxidation) at 1 $\mathrm{cm}$ intervals in the top $10 \mathrm{~cm}$, and at $2 \mathrm{~cm}$ intervals in the remainder of the core (cores from Stn MC were sectioned only at $2 \mathrm{~cm}$ intervals for pore water extraction). The subsamples were immediately placed in plastic ziplock bags with air excluded. Pore water was extracted using Rhizon soil moisture samplers (Liu et al. 2011) and placed in polypropylene plastic bottles. All samples were stored in the dark at $-20^{\circ} \mathrm{C}$ (Lasorsa \& Casas 1996) and analyzed immediately upon return to the laboratory. The near-bottom water $(1 \mathrm{~m}$ distance to bottom) was sampled for temperature and salinity determination.

\section{Analyses}

Temperature and salinity of near-bottom water were determined in situ using a multi-parameter water quality analyzer (Multi 350i, WTW). The concentration of dissolved oxygen (DO) in near-bottom water was measured using the Winkler titration method (Bryan et al. 1976). OM content in sediments was determined by weight loss upon ignition of the dried sediment at $550^{\circ} \mathrm{C}$ for $4 \mathrm{~h}$ (Santisteban et al. 2004), with a precision (relative standard deviation, RSD) of $1.0 \%(n=5)$. Porosity was determined by weight change before and after freeze-drying the sediment. The determination of reactive $\mathrm{Fe}\left(\mathrm{Fe}_{\mathrm{R}}\right)$ followed $\mathrm{Zhu}$ et al. (2012), using $0.2 \mathrm{~g}$ of dry sediment with $25 \mathrm{ml}$ of $50 \mathrm{~g} \mathrm{l}^{-1}$ sodium dithonite (buffered with $0.2 \mathrm{M}$ sodium citrate and $0.35 \mathrm{M}$ acetic acid to $\mathrm{pH} 4.8$ ), and shaking for $2 \mathrm{~h}$ for $\mathrm{Fe}_{\mathrm{R}}$ extraction. The extracts were measured by inductively coupled plasma-atomic emission spectrometry (Thermo 6300). The relative deviations of parallel determinations were less than $5.0 \%(n=5)$. The RIS concentration in sediments comprised the combined concentrations of AVS, pyrite-S, and ES, which were measured using the cold diffusion method followed by iodometric titration of the sulfide collected in alkaline zinc solution (Hsieh et al. 2002); the analytical precision was $4.3,1.8$, and $1.7 \%(\mathrm{n}=5)$ for the 3 measurements, respectively (Kang et al. 2014). The pore water sulfate was determined using an indirect titration method (Howarth 1978) that had an analytical precision of $0.2 \%(n=5)$.

\section{Calculations}

The rate constant of OM decomposition, which was calculated according to Wei et al. (2005), has been used to discuss the impact of OM reactivity (ease of decomposition) on sulfate reduction in the YS and the East China Sea (Kang et al. 2014).

To calculate the sulfate reduction rates (SRRs), we assumed that the OM in sediments was oxidized by sulfate-reducing bacteria based on first-order kinetics, which was performed on the rate function. The sulfate profile was best expressed by assuming that the sulfate concentration decreased exponentially with depth (Jørgensen 1978, Bowles et al. 2014). The rate function $\left(f(\mathrm{x})=a \cdot \mathrm{e}^{-b x}\right.$, where $a$ and $b$ are constants and $x$ is depth) was obtained by fitting the sulfate profile using an exponential decay (Jørgensen 1978, Bowles et al. 2014). The SRR at a given depth was then calculated based on the rate function, and the depth-integrated SRR was calculated. To facili- 


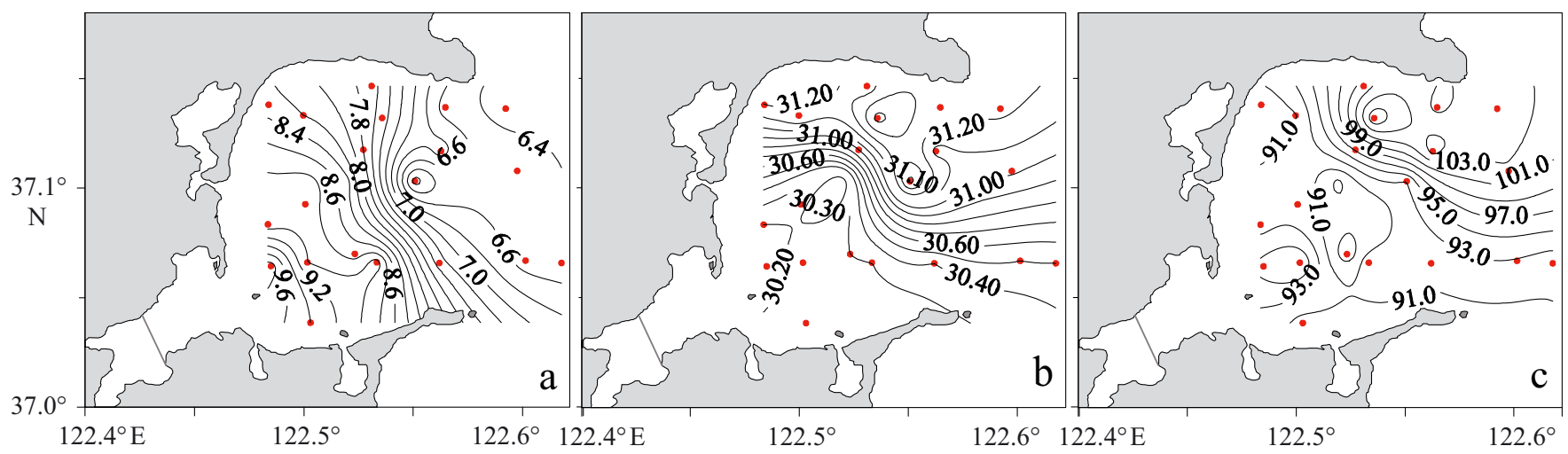

Fig. 2. Horizontal distributions of (a) temperature $\left({ }^{\circ} \mathrm{C}\right)$, (b) salinity, and (c) the degree of dissolved oxygen (DO) saturation $(\%)$ in near-bottom seawater of Sanggou Bay (see Fig. 1 for station locations, red dots)

tate consistent comparisons, the SRR was integrated to the bottom of the sulfate reduction zone (the integrated depth determined from extrapolations according the rate function).

\section{Statistics}

All statistical tests were performed using SPSS 19 software. Prior to each statistical analysis, the normality and homoscedasticity of the data were tested. One-way ANOVAs were applied to normalized data showing homogeneous variance. A 1-way ANOVA was used to assess differences in the OM and sulfide concentrations among various mariculture areas in the SGB. For all statistical tests, a probability of 0.05 was used to determine statistical significance. In factor analysis, principal component analysis (PCA) with varimax rotation was used to study the relationship among measured parameters. The number of principal components in the PCA model was established by considering only those with an eigenvalue $>1.0$ (Reid \& Spencer 2009).

\section{RESULTS}

\section{Physical and chemical parameters of near-bottom water in SGB}

The spatial distribution of temperature, salinity, and the degree of DO saturation in near-bottom water is shown in Fig. 2. The temperature of nearbottom water ranged from 6.1 to $9.9^{\circ} \mathrm{C}$ (mean $\pm \mathrm{SD}$ $7.8 \pm 1.2^{\circ} \mathrm{C}$ ) and decreased from the inner bay to the mouth. Salinity ranged from 30.10 to 31.44 (30.71 \pm 0.49 ) and decreased from the mouth to the inner bay.
There was a low-salinity zone in the west and southwest of the bay, near the Guhe River and Bahe reservoir. DO saturation ranged from 87.6 to $108.6 \%$ (mean 95.5\%), and was higher at the mouth than in the inner bay. There was a slightly lower DO zone from southeast to northwest of the bay.

\section{Quality and quantity of OM in sediments of SGB and YS}

The OM concentration ranged from 0.9 to $9.2 \%$ (mean $5.4 \%$ ) in surface sediment of SGB, and increased from the mouth of the bay $(4.08 \pm 0.95 \%)$ to the inner bay $(6.26 \pm 2.08 \%$; Table 1$)$, particularly in the scallop and oyster monoculture areas (Fig. 3a). The OM concentration decreased to a minimum of $3.5 \%$ with increasing depth in the deep layer at Stns MC and ST1 (Fig. 3b). The OM rapidly decreased in the upper $7 \mathrm{~cm}$ and then remained stable with depth at Stn A02. The rate constant of OM decomposition was $0.072,0.033$, and $0.001 \mathrm{yr}^{-1}$ at Stns MC, ST1, and A02, respectively, which indicated that the OM reactivity of Stn MC was the highest among the 3 stations.

\section{Sulfate in pore waters and sulphate reduction rate in SGB and YS}

The pore water sulfate concentration was high and fluctuated with increasing depth at Stns ST1, MC, and A02 (Fig. 4). The depth-integrated SRR was 1.89 and $0.54 \mathrm{mmol} \mathrm{m}^{-2} \mathrm{~d}^{-1}$ (X. Kang et al. unpubl. data) at Stns ST1 and A02, respectively. The SRR at Stn MC was not calculated because of the limited available pore water sulfate data. 
Table 1. Dissolved oxygen (DO) concentration in near-bottom water and organic matter (OM) and sulfide concentrations in sediments at stations in areas involved in 4 major types of mariculture in Sanggou Bay. We did not compile the data from fish monoculture regions, as only a limited number of stations were available. AVS: acid-volatile sulfide, ES: elemental sulfur, RIS: reduced inorganic sulfur

\begin{tabular}{|c|c|c|c|c|c|c|c|c|c|}
\hline \multirow{2}{*}{$\begin{array}{l}\text { Para- } \\
\text { meters }\end{array}$} & \multirow[t]{2}{*}{ Unit } & \multicolumn{2}{|c|}{ Scallop monoculture } & \multicolumn{2}{|c|}{ Oyster monoculture } & \multicolumn{2}{|c|}{ Scallop/kelp polyculture } & \multicolumn{2}{|c|}{ Kelp monoculture } \\
\hline & & Range & Mean (SD) & Range & Mean (SD) & Range & Mean (SD) & Range & Mean (SD) \\
\hline DO & $\mathrm{mg} \mathrm{l}^{-1}$ & $8.53-10.60$ & $9.20(0.85)$ & $8.38-9.22$ & $8.82(0.35)$ & $8.77-10.49$ & $9.58(0.75)$ & $9.22-10.43$ & $9.81(0.63)$ \\
\hline OM & $\%$ by dry wt & $4.71-7.48$ & $6.06(0.93)$ & $4.09-9.18$ & $6.26(2.08)$ & $4.47-7.25$ & $5.49(0.83)$ & $3.20-4.95$ & $4.08(0.95)$ \\
\hline AVS & $\mu \mathrm{mol} \mathrm{g} \mathrm{g}^{-1}$ & $0.58-5.00$ & $2.54(1.83)$ & $2.51-12.56$ & $5.87(5.79)$ & $0.20-5.00$ & $1.57(1.63)$ & $0.22-3.34$ & $1.12(1.49)$ \\
\hline Pyrite-S & $\mu \mathrm{mol} \mathrm{g} \mathrm{g}^{-1}$ & $8.78-51.52$ & $21.63(14.65)$ & $15.06-24.01$ & $21.40(4.18)$ & $5.45-38.52$ & $16.04(9.59)$ & $7.03-14.50$ & $11.06(3.17)$ \\
\hline ES & $\mu \mathrm{mol} \mathrm{g} \mathrm{g}^{-1}$ & $0.24-1.10$ & $0.65(0.34)$ & $0.28-0.86$ & $0.52(0.28)$ & $0.16-0.88$ & $0.48(0.21)$ & $0.24-0.34$ & $0.29(0.04)$ \\
\hline RIS & $\mu \mathrm{mol} \mathrm{g}{ }^{-1}$ & $12.68-53.19$ & $24.82(13.62)$ & $18.02-37.06$ & $25.71(7.20)$ & $5.81-39.91$ & $18.09(9.56)$ & $7.78-18.08$ & $12.46(4.33)$ \\
\hline
\end{tabular}

\section{Distribution of reactive Fe in surface and core sediments of SGB and YS}

Content of $\mathrm{Fe}_{\mathrm{R}}$ in surface sediments of SGB showed a wide range from 20.7 to $102.1 \mu \mathrm{mol} \mathrm{g}{ }^{-1}$. A peak value was observed in the scallop monoculture region (Fig. 5a). This spatial distribution was generally coupled to OM (Fig. 3a). The concentrations (in umol $\mathrm{g}^{-1}$ ) of $\mathrm{Fe}_{\mathrm{R}}$ were 26.0-93.6 (mean 60.6) at Stn MC, 18.0-148.3 (mean 62.0) at Stn ST1, and 29.8-126.1 (mean 82.5) at Stn A02, and all exhibited a decrease with greater core depth (Fig. 5b).

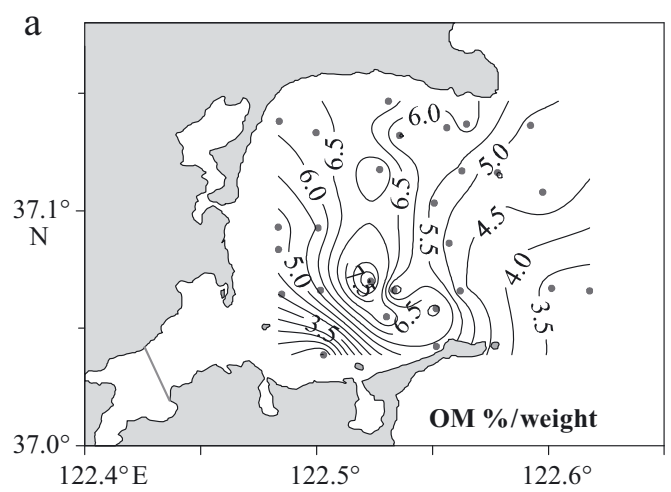

\section{Sediment porosity of surface and core sediments of SGB and YS}

The porosity of surface sediment ranged from 0.40 to 0.77 in SGB, presenting higher values in the inner bay with oyster or scallop monoculture and lower values in the mouth of the bay with kelp monoculture (Fig. 6a). The porosity at Stns ST1, MC, and A02 all exhibited a decrease with greater core depth, especially at Stn MC. The porosity of Stn ST1 decreased in the upper $5 \mathrm{~cm}$ and then remained stable with depth (Fig. 6b).

\section{Sulfur species in surface and core sediments of SGB and YS}

The concentrations (in $\mu \mathrm{mol} \mathrm{g}{ }^{-1}$ ) of AVS, pyrite-S, and ES in surface sediments of SGB were 0.20-12.56 (mean 2.20), 0.57-51.52 (mean 17.17), and 0.16-1.10 (mean 0.49), respectively. The differences in AVS, ES, and pyrite-S between stations in the SGB were significant at the 95\% confidence level. The AVS showed high concentrations in the southwest part of the bay (with oyster monoculture; Fig. 7). Compared
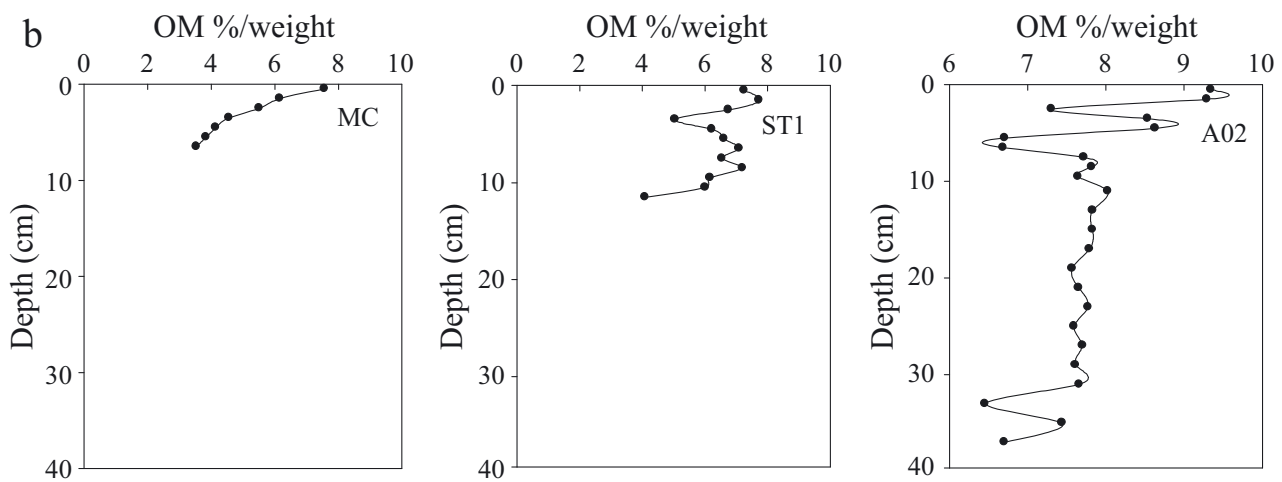

Fig. 3. Distribution of organic matter (OM) concentrations (\% by weight) in (a) surface and (b) core sediments of Sanggou Bay and the Yellow Sea (see Fig. 1 for station locations) 

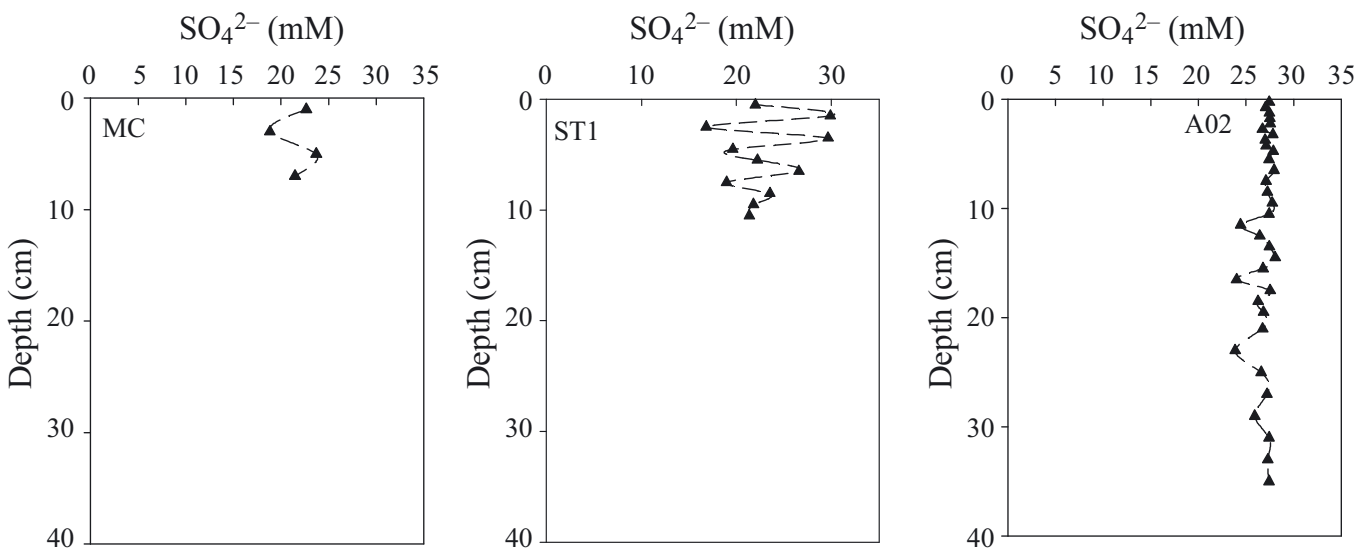

Fig. 4. Pore water profiles of sulfate at Stns ST1, MC, and A02 in Sanggou Bay (see Fig. 1 for station locations)

with AVS and pyrite-S, the concentrations of ES were lower throughout the bay, especially at the mouth. Pyrite-S was the predominant sulfide mineral in sediments of the bay, accounting for 58.2 to $96.9 \%$ (mean $85.0 \%$ ) of the RIS, and its concentration was particularly high in the northwest (with scallop monoculture) and south part (with oyster monoculture) of the bay.

The variations in AVS, ES, and pyrite-S with depth were significant at the $95 \%$ confidence level. The AVS concentration was $<12.56 \mu \mathrm{mol} \mathrm{g}^{-1}$ in core sedi-

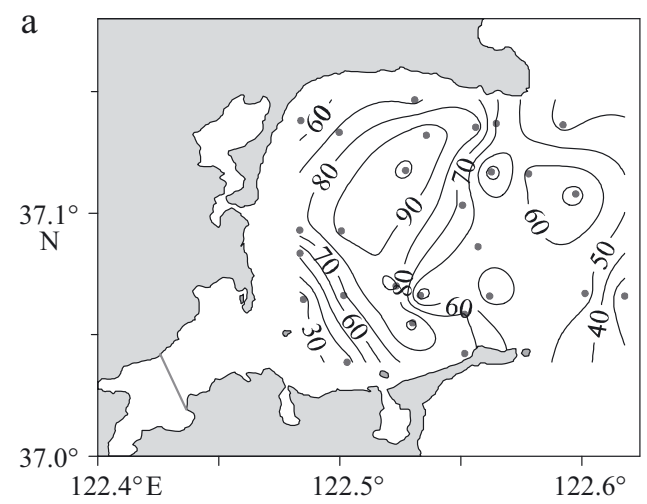

ments of SGB, as its accumulation was limited by transformation to pyrite-S. At Stn ST1, the AVS concentration gradually increased in the upper $7 \mathrm{~cm}$ and then stabilized, while the pyrite-S concentration peaked at 2-3 cm depth, then leveled off below this depth (Fig. 8). At Stn MC, we observed 2 peaks of AVS and pyrite-S concentration. The ES concentration was stable with increasing depth at Stns ST1 and MC; pyrite-S was the primary sulfide at these 2 stations. For Stn A02, the AVS concentration was low and only peaked at $8 \mathrm{~cm}$. ES and pyrite-S increased with depth at this station and were comparable to SGB. The distribution of ES was similar to that of pyrite-S at Stn A02. Pearson's correlation analysis revealed a significant positive correlation between the ES and pyrite-S concentrations $(\mathrm{r}=0.62, \mathrm{p}<0.001)$.

\section{PCA}

We performed PCAs of sulfur speciation, OM, $\mathrm{Fe}_{\mathrm{R}}$ and porosity. The total variances explained by the first 3 and 2 principal components were $86.45 \%$ and
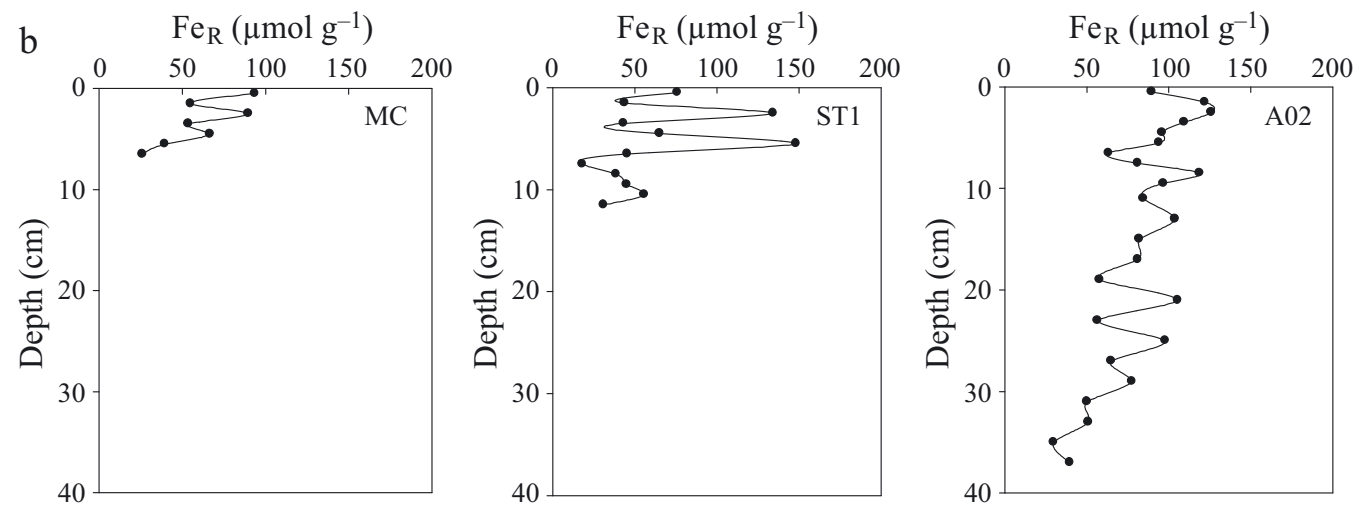

Fig. 5. Distribution of reactive iron $\left(\mathrm{Fe}_{\mathrm{R} i} \mu \mathrm{mol} \mathrm{g}^{-1}\right.$ ) in (a) surface and (b) core sediments of Sanggou Bay and the Yellow Sea (see Fig. 1 for station locations) 
$78.04 \%$, respectively, for surface and core sediments. The degree of association between each variable and each principal component was given by its loading on that principal component.

For surface sediments (Table 2), PC1 accounted for $38.17 \%$ of the total variance and was correlated primarily with ES, pyrite-S, and RIS. PC2 accounted for $32.83 \%$ of the total variance and correlated with $\mathrm{Fe}_{\mathrm{R}}$, OM, and porosity. PC3 accounted for $15.45 \%$ of the

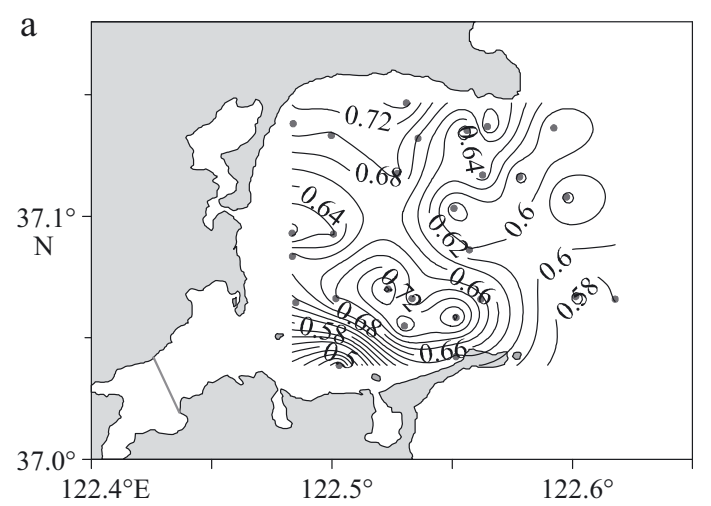

total variance and was primarily characterized by a positive loading of AVS and a negative loading of ES.

For core sediments (Table 3), PC1 accounted for $55.20 \%$ of the total variance, and was positively associated with AVS, pyrite-S, and RIS, and negatively correlated with $\mathrm{OM}, \mathrm{Fe}_{\mathrm{R}}$, and porosity. PC2 accounted for $22.84 \%$ of the total variance and was positively correlated with ES and negatively correlated with AVS.
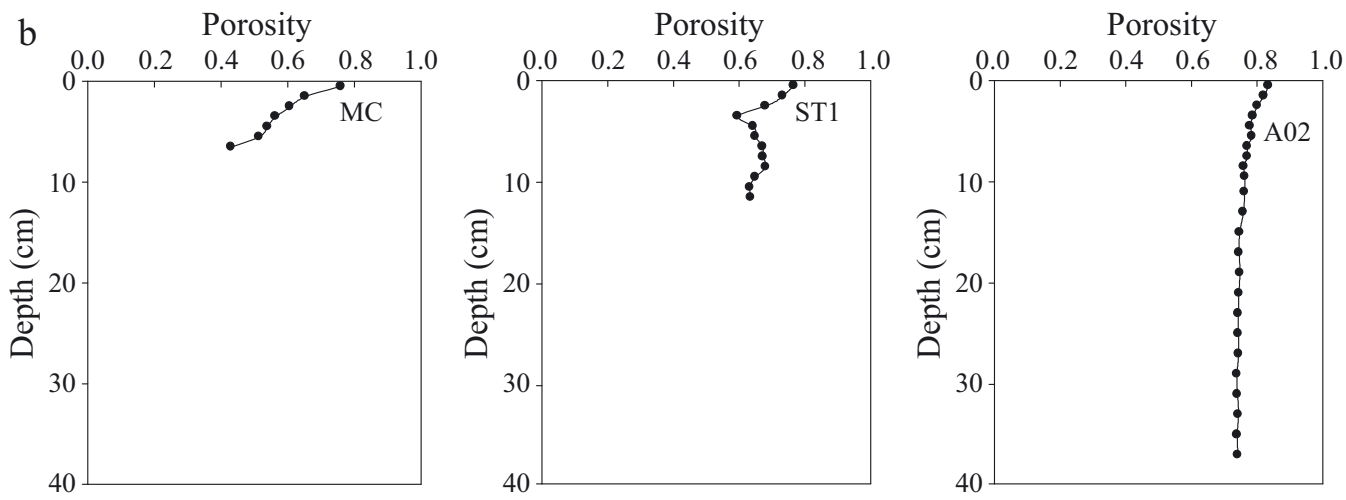

Fig. 6. Porosity of (a) surface and (b) core sediments of Sanggou Bay and the Yellow Sea (see Fig. 1 for station locations)

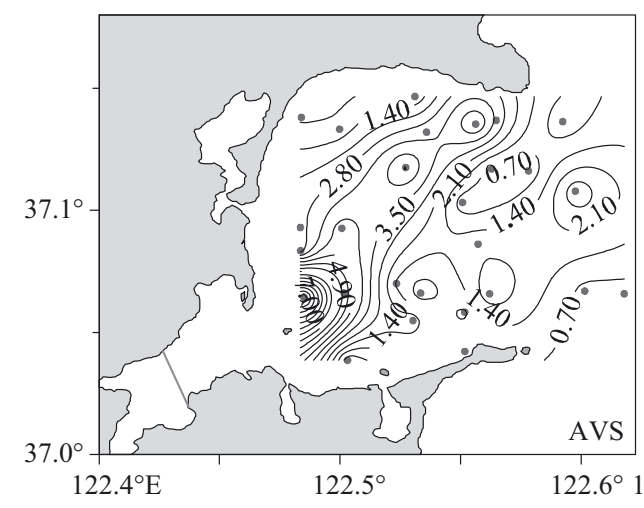

AVS

$122.4^{\circ} \mathrm{E}$

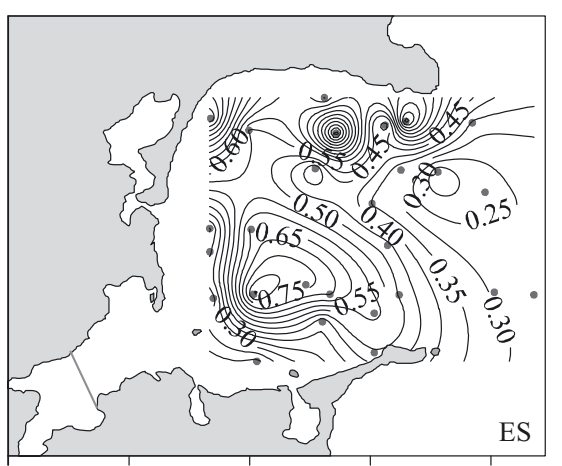

$122.5^{\circ}$

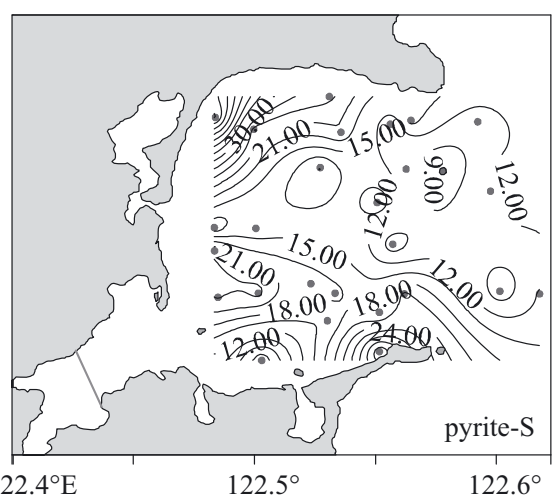

$122.6^{\circ}$

Fig. 7. Horizontal distributions of acid-volative sulfide (AVS), elemental sulfur (ES), and pyrite-S ( $\mu \mathrm{mol} \mathrm{g}^{-1}$ ) in surface sediments of Sanggou Bay 


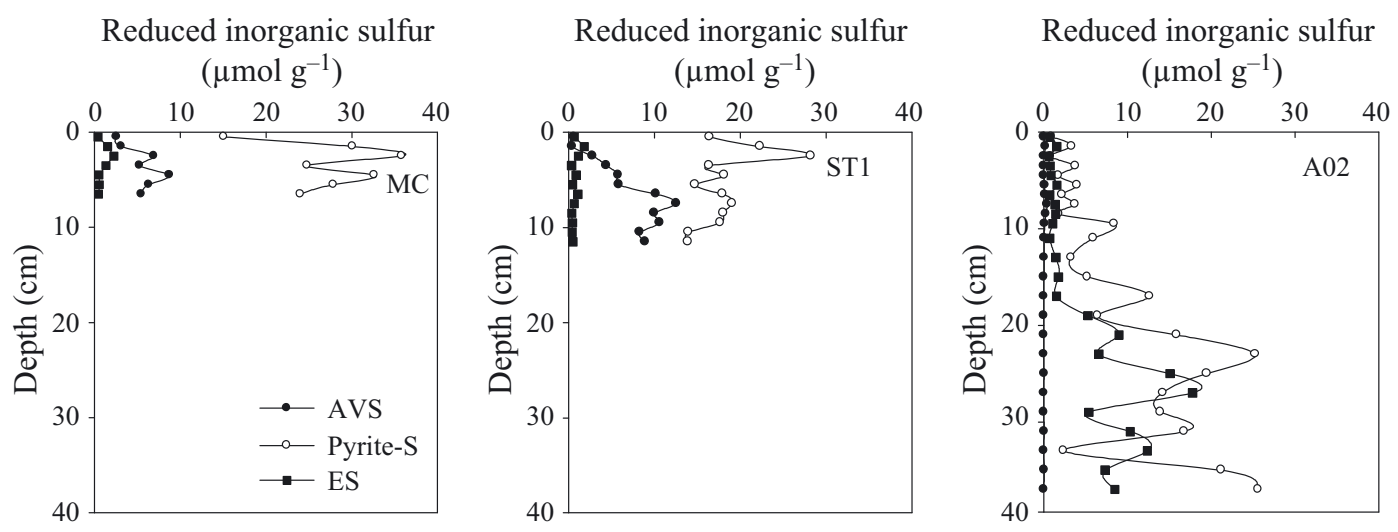

Fig. 8. Vertical distribution of reduced inorganic sulfur in sediments of Sanggou Bay and the Yellow Sea (see Fig. 1 for station locations)

Table 2. Principal component analysis for surface sediments of Sanggou Bay. AVS: acid-volatile sulfide, ES: elemental sulfur, RIS: reduced inorganic sulfur, OM: organic matter

\begin{tabular}{|lrrrc|}
\hline & PC1 & PC2 & PC3 & $\begin{array}{c}\text { Commu- } \\
\text { nalities }\end{array}$ \\
\hline AVS & 0.05 & 0.05 & 0.98 & 0.97 \\
ES & 0.67 & 0.42 & -0.25 & 0.69 \\
Pyrite-S & 0.97 & 0.07 & -0.01 & 0.95 \\
RIS & 0.96 & 0.09 & 0.22 & 0.97 \\
OM & 0.29 & 0.90 & -0.02 & 0.90 \\
Fe & -0.11 & 0.87 & 0.07 & 0.77 \\
Porosity & 0.52 & 0.74 & 0.02 & 0.81 \\
Eigenvalue & 2.67 & 2.30 & 1.08 & - \\
\% of variance & 38.17 & 32.83 & 15.45 & - \\
Cumulative & 38.17 & 71.00 & 86.45 & - \\
\% of variance & & & & \\
\hline
\end{tabular}

Table 3. Principal component analysis for core sediments of the study sites. AVS: acid-volatile sulfide, ES: elemental sulfur, RIS: reduced inorganic sulfur, OM: organic matter

\begin{tabular}{|lrrc|}
\hline & PC1 & PC2 & Communalities \\
\hline AVS & 0.65 & -0.58 & 0.75 \\
ES & 0.14 & 0.94 & 0.90 \\
Pyrite-S & 0.89 & 0.06 & 0.80 \\
RIS & 0.94 & 0.19 & 0.93 \\
OM & -0.79 & 0.41 & 0.79 \\
Fe & -0.65 & -0.01 & 0.42 \\
Porosity & -0.84 & 0.42 & 0.88 \\
Eigenvalue & 3.86 & 1.60 & - \\
\% of variance & 55.20 & 22.84 & - \\
Cumulative & 55.20 & 78.04 & - \\
\% of variance & & & \\
\hline
\end{tabular}

\section{Oxygen concentration}

Sulfate reduction is a strictly anaerobic process and mainly occurs in anoxic environments (Berner 1982, Jørgensen 1982, Aller \& Rude 1988). However, the primary effects of aerobic environments on sulfate reduction are through the re-oxidation of sulfide and the activity of sulfate-reducing bacteria (SRB). Aerobic mineralization may take place in oxic surface sediments in SGB. The extent of aerobic mineralization depends on the DO concentration in bottom water, which subsequently influences the extent of sulfate reduction (Brüchert et al. 2003). The SRR has been shown to be negatively correlated with bottom water oxygen concentration in the seasonally hypoxic Eckernförde Bay in the Baltic Sea (Bertics et al. 2013). In the present study, slightly lower DO concentrations were found in the scallop and oyster monoculture areas of SGB (Fig. 2c), which were related to the relatively high oxygen consumption associated with the process of OM decomposition. Low DO concentrations would have facilitated the activity of SRB and reduced the possibility of sulfide re-oxidation, leading to high concentrations of sulfide (especially the AVS and pyrite-S) in the scallop and oyster monoculture areas of SGB (Table 1). Thus, the DO concentration might regulate the distribution of RIS. Pearson's correlation analysis indicated a significant negative correlation between the DO concentration and the RIS concentration $(r=-0.48, p<0.05)$, indicating that the RIS concentration increased with decreasing DO concentration.

\section{Reactivity of OM}

The reactivity and quantity of OM are important factors controlling sulfate reduction (Berner 1984). The labile $\mathrm{OM}$ in mariculture regions would favor sulfate reduction (Otero et al. 2006). Although the reactivity of OM in SGB was not measured directly, it can be evaluated by calculating the TOC:total nitrogen (TN) ratio. Holmer \& Kristensen (1992) noted 
that OM with a low TOC:TN ratio (5.7-7.0) can be decomposed rapidly, within several months of closure of a fish farm. The TOC:TN ratio of OM in sediments of SGB has been reported to be in the range of 7.04 to 8.93 (Zhang et al. 2006), which is similar to the mean TOC:TN ratio (6.6) of labile OM in the ocean (Babbin et al. 2014). The decreased OM concentration in the top $4 \mathrm{~cm}$ of sediment at Stn ST1 might be related to decomposition of kelp mariculture debris and scallop fecal material. Compared to Stn ST1, a continuous decline in the $\mathrm{OM}$ concentration from the sediment surface to $7 \mathrm{~cm}$ depth was found at Stn MC, suggesting somewhat higher reactivity of OM in oyster monoculture areas. The high OM decomposition rate constant found at Stn MC also confirmed this phenomenon. The low decomposable characteristics of OM at Stn A02 are also confirmed by the low OM decomposition rate constant $\left(0.001 \mathrm{yr}^{-1}\right)$.

\section{Sulfate reduction}

Sulfate reduction is independent of the sulfate concentration until the concentration is $<3 \mathrm{mM}$ (Boudreau \& Westrich 1984). High concentrations of sulfate in pore water of the sediments of SGB and the reference station (A02) showed that sulfate was not a limiting factor for sulfate reduction. The SRR at Stn ST1 was higher than that at Stn A02, which might be related to the high reactivity of $\mathrm{OM}$ in the mariculture regions (Otero et al. 2006). The SRR in sediments of SGB was much lower than that in a marine fish farm (9-34 mmol m${ }^{-2} \mathrm{~d}^{-1}$ ) in Kolding Fjord, Denmark, with higher OM concentration (up to $23 \%$ ) in sediments (Holmer \& Kristensen 1992).

\section{Other factors that influence sulfide distribution}

Sediment grain size often influences the OM decomposition and sulfide accumulation in marine ecosystems (Martinez-Garcia et al. 2015). The grain size was not determined in this study, and data of the porosity were used here because finer-grain sediments tend to have higher porosities than coarser materials (Buckingham 2005). Our PCA results showed that porosity could influence the distribution of $\mathrm{Fe}_{\mathrm{R}}$ and $\mathrm{OM}$ in surface and core sediments, and subsequently affected the profiles of AVS and pyrite$\mathrm{S}$. In addition, $\mathrm{Fe}_{\mathrm{R}}$ was closely associated with OMrich sediments. AVS could oxidize to ES, and the latter had a significant influence on the accumulation of pyrite-S in surface sediments, as highlighted by the
PCA results (Table 2). The high ratio ( $>3$ ) of pyrite-S to AVS in the core sediments and the PCA results both showed that the AVS could convert to pyrite-S effectively.

The current velocity can also influence the sulfide distribution; for example, the decreased current velocity (up to $54 \%$ ) (Grant \& Bacher 2001) caused by the presence of dense mariculture restricted the DO exchange between SGB and the water outside the bay. In addition, the movement of OM could also be influenced by the current. These 2 cases can influence the sulfate reduction, and consequently influence the sulfide distribution. Our results showed that high concentrations of sulfide distribution coupled well with lower current velocity (Grant \& Bacher 2001). Furthermore, the sulfide distribution could also be influenced by water depth, and there was a significant negative correlation between the RIS concentration and water depth (Pearson $\mathrm{r}=-0.41, \mathrm{p}<0.05$ ).

\section{Mariculture impacts on sulfide accumulation and the benthic environment}

Mariculture impacts on sulfide accumulation

Although in addition to mariculture, natural factors can also impact the sulfide accumulation in sediments, the weak impact of natural factors could be ignored in our study area. For example, river input carries an annual sediment load of up to $17.1 \times 10^{4} \mathrm{t}$, with a mean OM concentration of $4.5 \%$ in sediment of rivers around SGB (Xia 1991), which was lower than that in SGB (5.4\%). RIS concentration in sediment of the Xiaoluo River (the second largest river around SGB) was determined in our previous study (X. Kang et al. unpubl.), and concentrations of AVS, pyrite-S, and ES were 0.56, 6.63, and $0.66 \mu \mathrm{mol} \mathrm{g}{ }^{-1}$, respectively, much lower than those in SGB. Thus, natural factors were not considered in the current study; instead, we focused on the influence of mariculture on sulfide accumulation.

The concentrations of sulfide in various mariculture areas are shown in Table 1 . We found no significant difference in the AVS concentration between any 2 regions, except between the oyster monoculture and the scallop/kelp polyculture areas. The AVS concentration in the oyster monoculture areas was significantly higher (by a factor of 3.74) than in the scallop/kelp polyculture areas (1-way ANOVA, $\mathrm{p}<0.05$ ). AVS concentrations accumulated in oyster monoculture areas were 1.5-fold higher than values in the scallop/kelp polyculture areas owing to dense 
mariculture. This additional AVS accumulation might be related to the sedimentation rate in the oyster monoculture areas, which was significantly higher than in the scallop/kelp polyculture areas in spring (Cai et al. 2003). High sedimentation rates favor the retention of AVS in sediments (Gagnon et al. 1995). In addition, dense mariculture also influences the current velocity, which consequently influences the AVS accumulation. We observed no significant difference in the pyrite-S and RIS concentrations between 2 randomly selected regions, except between the oyster and kelp monoculture areas. The pyrite-S and RIS concentrations in the oyster monoculture areas were significantly higher than in the kelp monoculture areas (1-way ANOVA, p < 0.05), with the mean concentrations in the former areas being higher by a factor of 2.0. The higher concentrations of AVS, pyrite-S, and RIS in the oyster monoculture areas were related to the higher OM and lower DO concentrations (Table 1). In addition, release of DO to the water column through photosynthesis would be occurring in the kelp mariculture areas. There was no significant difference in the ES concentration between 2 randomly selected regions. It may be that as an intermediate form of sulfide, ES is reduced to $\mathrm{H}_{2} \mathrm{~S}$ under reducing conditions, and oxidized to sulfate in oxic environments (Lovley \& Phillips 1994).

Mariculture also influences sulfur accumulation in core sediments. Pyrite-S and RIS were significantly higher at Stn MC than Stn ST1 (1-way ANOVA, p < $0.05)$, although the $\mathrm{OM}$ was significantly lower at MC compared to ST1 (1-way ANOVA, $\mathrm{p}<0.05$ ). This phenomenon may have been induced by the higher reactivity of $\mathrm{OM}$ at Stn MC. However, there was no significant difference in AVS, ES, and $\mathrm{Fe}_{\mathrm{R}}$ between Stns ST1 and MC (1-way ANOVA, p > 0.05). AVS, pyrite-S, and RIS concentrations at Stns ST1 and MC were significantly higher than at the reference station (A02) (1-way ANOVA, p < 0.05). However, there was no significant difference of $\mathrm{Fe}_{\mathrm{R}}$ among Stns ST1, $\mathrm{MC}$, and A02 (1-way-ANOVA, p > 0.05). In addition, the OM at ST1 and MC was significantly lower than at A02 (1-way ANOVA, p < 0.05). The relatively lower OM at Stns ST1 and MC induced high concentrations of AVS, pyrite-S, and RIS and may be related to its high reactivity owing to mariculture. ES was significantly higher at A02 than at MC and ST1 (1-way ANOVA, p < 0.05), which might be related to the AVS oxidation.

Compared with the RIS concentration in other mariculture areas (Table 4), the AVS concentration in SGB was in the same range as reported for Laizhou Bay, Zhangzi Island, for scallop and sea cucumber mariculture (Gao et al. 2013), Bohai Bay for clam mariculture (Jiang et al. 2005), and Jiaozhou Bay for clam and shrimp mariculture (Huo et al. 2001). Hyun et al. (2013) compiled the SRRs for various mariculture regions, and noted that SRR was related to sedimentation rates of organic carbon, hanging mussel biomass, the length of time a farm had been in operation, and temperature. It is difficult to say which factor(s) accounts for the similar concentrations of RIS among these mariculture areas. In general, the RIS concentrations in shellfish farms (including scallop, oyster, and clam farms) were lower than in fish farms, including the Dapengao Bay fish cage mariculture farm (Gan et al. 2003). The difference in RIS concentration between shellfish and fish farms is largely because of the higher sedimentation rate of food pellets in fish farms, which provide additional OM. Compared with non-mariculture regions, such as the adjacent YS (Pu et al. 2008, Kang et al. 2014), there was no significant accumulation of AVS in SGB. The RIS concentration in SGB was lower than that in the East China Sea (Lin et al. 2002, Kang et al. 2014), the Black Sea (Holmkvist et al. 2011), and the Mediterranean Sea (Henneke et al. 1997). As SGB is an integrated multi-trophic aquaculture bay, kelp may assimilate nutrients and release DO into the water column through photosynthesis. The lower TOC concentrations and aerobic environment may explain the lower RIS concentrations in SGB.

Mariculture impacts on the benthic environment

One of the main impacts of mariculture on the benthic environment is $\mathrm{OM}$ enrichment of sediments through biodeposition. The OM concentration in the scallop monoculture and the scallop/kelp polyculture areas were slightly higher (by factors of 1.49 and 1.35, respectively) than in the kelp monoculture areas (1-way ANOVA, p < 0.05). However, the OM concentration in the surface sediments of SGB was comparable to that in the adjacent YS (Fig. 3) (Kang et al. 2014). Crawford et al. (2003) noted that the effect of shellfish farming on organic enrichment of the seabed was small, and much less than that caused by finfish farming. In addition, the resuspension of surface sediment, driven by wind, waves, and currents, can be observed in spring in SGB (Jiang et al. 2012); these factors can resuspend and move most of the accumulated OM (Holmer \& Kristensen 1992). Dissimilatory sulfate reduction through OM decomposition may also be responsible for the low OM concentration in SGB. 
Table 4. Concentrations of various sulfur species in the sediments of Sanggou Bay in comparison to other sea regions. AVS: acid-volatile sulfide, ES: elemental sulfur, TOC: total organic carbon, ND: no data

\begin{tabular}{|c|c|c|c|c|c|}
\hline Location & AVS $\left(\mu \mathrm{mol} \mathrm{g}{ }^{-1}\right)$ & Pyrite-S $\left(\mu \mathrm{mol} \mathrm{g} \mathrm{g}^{-1}\right)$ & $\mathrm{ES}\left(\mu \mathrm{mol} \mathrm{g}{ }^{-1}\right)$ & TOC (\%/weight) & Reference \\
\hline \multicolumn{6}{|l|}{ Mariculture present } \\
\hline Sanggou Bay & $0.20-12.56$ & $0.57-51.52$ & $0.16-1.10$ & $0.48-0.70^{\mathrm{a}}$ & This study \\
\hline Northern of Bohai Bay & $1.02-13.68$ & ND & ND & ND & Jiang et al. (2005) \\
\hline Laizhou Bay & $1.22-7.60$ & ND & ND & $0.12-2.18$ & Gao et al. (2013) \\
\hline Zhangzi Island & $0.71-11.03$ & ND & ND & $0.12-2.18$ & Gao et al. (2013) \\
\hline Jiaozhou Bay & $5.06-19.11$ & ND & ND & ND & Huo et al. (2001) \\
\hline Dapengao Bay & $4.44-29.66$ & ND & ND & ND & Gan et al. (2003) \\
\hline \multicolumn{6}{|l|}{ Mariculture absent } \\
\hline Yellow Sea & $0.02-17.14$ & $0.61-113.1$ & $0-44.4$ & $0.22-0.94$ & Kang et al. (2014) \\
\hline East China Sea & $0.01-25.02$ & $0.61-54.82$ & $0.14-16.84$ & $0.32-1.05$ & Kang et al. (2014) \\
\hline Southern Yellow Sea & $0-11.14$ & ND & ND & ND & Pu et al. (2008) \\
\hline Southern East China Sea & $0-25$ & $0-240$ & ND & $0.50-0.80$ & Lin et al. (2002) \\
\hline Black Sea & $0-36$ & $0-380$ & $0-16$ & $0.33-15.00$ & Holmkvist et al. (2011) \\
\hline Mediterranean Sea & $5-25$ & $50-350$ & $0-25$ & $0.50-9.50$ & Henneke et al. (1997) \\
\hline
\end{tabular}

The mean benthic carbon oxidation rate in SGB was $8.97 \mathrm{mmol} \mathrm{C} \mathrm{m} \mathrm{m}^{-2}$ (Z. Ning et al. unpubl. data), calculated from the Redfield stoichiometric $\mathrm{C}: \mathrm{O}_{2}$ ratio (1:1) and oxygen utilization (Ning et al. 2016). Similarly, from the stoichiometric conversion of sulfate reduction to $\mathrm{C}$ oxidation (i.e. $\mathrm{C}: \mathrm{S}=2: 1$ ) (Hyun et al. 2013), the contribution of sulfate reduction to total $C$ oxidation was estimated. Calculation of the C oxidation rate, based on the SRR at Stn ST1 and its proportion of the total carbon oxidation rate, suggests that $42.1 \%$ of total C oxidation occurs via sulfate reduction in sediments of SGB. In addition, the contribution of denitrification to total $\mathrm{C}$ oxidation ranges from 4 to $10 \%$ in SGB (Ning et al. 2016). The remaining $\mathrm{C}$ oxidation may be a consequence of aerobic respiration, iron reduction, manganese reduction, and methanogenesis in SGB. However, the contribution of sulfate reduction to $\mathrm{C}$ oxidation in SGB may be underestimated, because Stn ST1 was located in the polyculture area, where sulfate reduction was relatively weak, in part as a result of the low OM concentration. The contribution of sulfate reduction to C oxidation in SGB is higher than that at Stn A02 (30.0\%) and lower than that found in July in the Jinhae-Tongyeong coastal mariculture region (64.4\%) (Hyun et al. 2013) and that found in May in marine fish farm sediments of Kolding Fjord, Denmark (59.0\%) (Holmer \& Kristensen 1992).

Among the environmental and ecological issues arising from sulfate reduction in OM-enriched coastal sediments is the release of nutrients, including phosphate and ammonium, into the overlying water (Hyun et al. 2013). The benthic fluxes were -21 to
$-7.7,7.7$ to 21,0 to $0.51,-0.030$ to $0.27,-1.01$ to 0.63 , and 0.83 to $1.76\left(\mathrm{mmol} \mathrm{m}^{-2} \mathrm{~d}^{-1}\right)$ for $\mathrm{DO}, \mathrm{CO}_{2}, \mathrm{NH}_{4}$, $\mathrm{NO}_{\mathrm{X}}{ }^{-}\left(\mathrm{NO}_{2}{ }^{-}+\mathrm{NO}_{3}{ }^{-}\right)$, dissolved organic nitrogen, $\mathrm{PO}_{4}{ }^{3-}$, and $\mathrm{Si}(\mathrm{OH})_{4}$, respectively, in SGB (Ning et al. 2016), and the benthic nutrient fluxes were significantly lower in polyculture areas than in the monoculture areas.

\section{Ecological implications of sulfide accumulation} in SGB

Sulfide tolerance (e.g. $\mathrm{H}_{2} \mathrm{~S}$ ) of benthic fauna has previously been used to study the ecological significance of sulfide in sediment (Vismann 1991). The viability of fish farming can be at risk from the release of $\mathrm{H}_{2} \mathrm{~S}$ via sulfate reduction from sediments to the water column (Yokoyama 2003). Thus, we evaluated the ecological state of SGB according the sulfide distribution. The direct determination of $\mathrm{H}_{2} \mathrm{~S}$ was difficult in SGB as a result of the low concentrations of sulfide in the marginal East China Sea of China (Zhu et al. 2013, Kang et al. 2014). The AVS concentration can be used as a key index for evaluating aquaculture environments (Sanz-Lázaro \& Marin 2006). Therefore, we used AVS variations instead of $\mathrm{H}_{2} \mathrm{~S}$ to analyze the ecological state of SGB. Previous studies have indicated that the macrobenthic biomass decreases with increasing AVS concentration in the sediments, and little macrobenthic biota occurs in sediments when the concentration of AVS is higher than $53.1 \mu \mathrm{mol} \mathrm{g} \mathrm{g}^{-1}$ (Yokoyama 2003). However, the concentration of 
AVS (range 0.20-12.56 $\mu_{\mathrm{mol} \mathrm{g}}{ }^{-1}$ ) in sediments never exceeded this critical value in SGB.

Sulfur is also of ecological significance in the energy dynamics of sediments in SGB. The following discussion is based on calculations and assumptions detailed by Howarth (1984). During the process of sulfate reduction, generally $75 \%$ of the energy in the OM is transferred and fixed as hydrogen sulfide (Howarth 1984). Therefore, given that $42.1 \%$ of the total carbon oxidation was caused by sulfate reduction in SGB sediments, $31.6 \%$ (75\% of $42.1 \%$ ) of the energy transferring through the sediment would be conserved as hydrogen sulfide. Most of the hydrogen sulfide quickly forms iron sulfide, of which 80 to $99 \%$ is reoxidized under aerobic conditions (Howarth 1984). Based on the given calculation method of Howarth (1984) in Limfjorden sediments, approximately $10.0 \%$ of reduced sulfur was assumed to be buried in SGB sediments perpetually, and thus the energy released from reduced sulfur reoxidation would account for $28.4 \%$ (90\% of $31.6 \%$ ) of the benthic OM decomposition here. Thus, the released energy would total $1.3 \mathrm{KJ} \mathrm{m}^{-2} \mathrm{~d}^{-1}$, corresponding to a total respiration of $4.6 \mathrm{KJ} \mathrm{m}^{-2} \mathrm{~d}^{-1}\left(0.11 \mathrm{~g} \mathrm{C} \mathrm{m}^{-2} \mathrm{~d}^{-1}\right)$ in SGB sediments. This released energy could be used by chemolithoautotrophs for $\mathrm{CO}_{2}$ fixation, with energy utilization efficiency ranging from 21 to $37 \%$ in sediments (Howarth 1984). Subsequently, new organic carbon (0.007 to $0.012 \mathrm{~g} \mathrm{C} \mathrm{m}^{-2} \mathrm{~d}^{-1}$ ) was input to SGB sediments. This new organic carbon produced at the oxic-anoxic interface by chemolithoautotrophic production could be used as food for benthic animals (Howarth 1984).

\section{CONCLUSION}

We found that under the combined effects of mariculture activities and physicals factors, the RIS was affected in the study area. RIS concentration showed spatial differences with mariculture species. Compared with the oyster monoculture area, the relatively low OM and RIS accumulation in the scallop/kelp polyculture areas demonstrated the environmental benefits of this culture practice. We observed no significant influence of mariculture on the benthic environment after several years of mariculture in SGB, although it promoted sulfide accumulation to some extent compared to the reference station. The lower intensity of culture activities, better hydrodynamic conditions, and the polyculture of scallops and kelp might explain the healthy benthic environment in SGB (Zhang et al. 2009). In addition, the ecological state of SGB can be assessed using the RIS concentration in sediment.

Although we investigated the effect of mariculture activities on RIS accumulation, the seasonal evolution of the system was not considered in this study, and should therefore be assessed in future research. In addition, the mariculture facilities should be considered further to better evaluate the influence of mariculture.

Acknowledgements. We thank Zhaomeng Xu and Wangwang Ye for help in sample collection, and Zhiming Ning for help with DO measurements and suggestions during revisions to this paper. We thank the editor and 4 anonymous reviewers for comments on an earlier version of this paper. This research was funded by the Ministry of Science \& Technology of China (2011CB409802), and the National Science Foundation of China (40925017 and 41221004).

\section{LITERATURE CITED}

Aller RC, Rude PD (1988) Complete oxidation of solid phase sulfides by manganese and bacteria in anoxic marine sediments. Geochim Cosmochim Acta 52:751-765

Babbin AR, Keil RG, Devol AH, Ward BB (2014) Organic matter stoichiometry, flux, and oxygen control nitrogen loss in the ocean. Science 344:406-408

Berner RA (1982) Burial of organic carbon and pyrite sulfur in the modern ocean: its geochemical and environmental significance. Am J Sci 282:451-473

Berner RA (1984) Sediment pyrite formation: an update. Geochim Cosmochim Acta 48:605-615

Bertics VJ, Löscher CR, Salonen I, Dale AW, Gier J, Schmitz RA, Treude T (2013) Occurrence of benthic microbial nitrogen fixation coupled to sulfate reduction in the seasonally hypoxic Eckernförde Bay, Baltic Sea. Biogeosciences 10:1243-1258

> Boudreau BP, Westrich JT (1984) The dependence of bacterial sulfate reduction on sulfate concentration in marine sediments. Geochim Cosmochim Acta 48:2503-2516

> Bowles MW, Mogollón JM, Kasten S, Zabel M, Hinrichs K (2014) Global rates of marine sulfate reduction and implications for sub-sea-floor metabolic activities. Science 344:889-891

Brüchert V, Jørgensen BB, Neumann K, Riechmann D, Schlösser M, Schulz H (2003) Regulation of bacterial sulfate reduction and hydrogen sulfide fluxes in the central Namibian coastal upwelling zone. Geochim Cosmochim Acta 67:4505-4518

Bryan JR, Riley JP, Williams PJL (1976) A Winkler procedure for making precise measurements of oxygen concentration for productivity and related studies. J Exp Mar Biol Ecol 21:191-197

> Buckingham MJ (2005) Compressional and shear wave properties of marine sediments: comparisons between theory and data. J Acoust Soc Am 117:137-152

Burton ED, Bush RT, Sullivan LA (2006) Fractionation and extractability of sulfur, iron and trace elements in sulfide sediments. Chemosphere 64:1421-1428

Cai LS, Fang JG, Liang XP (2003) Natural sedimentation in large scale aquaculture areas of Sungo Bay, north 
China Sea. J Fish Sci China 10:305-310 (in Chinese with English Abstract)

- Carlsson MS, Holmer M, Petersen JK (2009) Seasonal and spatial variations of benthic implications of mussel longline farming in a eutrophic Danish fjord, Limfjorden. J Shellfish Res 28:791-801

Chopin T, Robinson SMC, Troell M, Neori A, Buschmann AH, Fang JG (2008) Multitrophic integration for sustainable marine aquaculture. In: Jørgensen SE, Fath BD (eds) Encyclopedia of ecology. Elsevier, Oxford, p 2463-2475

Crawford CM, Macleod CKA, Mitchell IM (2003) Effects of shellfish farming on the benthic environment. Aquaculture 224:117-140

Fang JG, Sun HL, Yan JP, Kuang SH, Li F (1996) Polyculture of scallop Chlamys farreri and kelp Laminaria japonica in Sungo Bay. Chin J Oceanol Limnol 14:322-329

FAO (Food and Agriculture Organization of the United Nations) (2012) The state of world fisheries and aquaculture. FAO, Rome

> Gagnon C, Mucci A, Pelletier É (1995) Anomalous accumulation of acid volatile sulphides (AVS) in a coastal marine sediment, Saguenay Fjord, Canada. Geochim Cosmochim Acta 59:2663-2675

Gan JL, Lin Q, Huang HH, Cai WG and others (2003) Distribution, variation and pollution of the sulfide in surfacial sediment at cage culture area in Dapengao Bay. J Fish Sci China 27:570-574 (in Chinese with English Abstract)

> Gao XL, Li PM, Chen CT (2013) Assessment of sediment quality in two important areas of mariculture in the Bohai Sea and the northern Yellow Sea based on acid-volatile sulfide and simultaneously extracted metal results. Mar Pollut Bull 72:281-288

> Grant J, Bacher C (2001) A numerical model of flow modification induced by suspended aquaculture in a Chinese bay. Can J Fish Aquat Sci 58:1003-1011

> Henneke E, Luther GW III, De Lange GJ, Hoefs J (1997) Sulphur speciation in anoxic hypersaline sediments from the Eastern Mediterranean Sea. Geochim Cosmochim Acta 61:307-321

> Holmer M, Kristensen E (1992) Impact of marine fish cage farming on metabolism and sulfate reduction of underlying sediments. Mar Ecol Prog Ser 80:191-201

> Holmkvist L, Kamyshny A Jr, Vogt C, Vamvakopoulos K, Ferdelman TG, Jørgensen BB (2011) Sulfate reduction below the sulfate methane transition in Black Sea sediments. Deep-Sea Res I 58:493-504

> Howarth RW (1978) A rapid and precise method for determining sulfate in seawater, estuarine waters, and sediment pore waters. Limnol Oceanogr 23:1066-1069

Howarth RW (1984) The ecological significance of sulfur in the energy dynamics of salt marsh and coastal marine sediments. Biogeochemistry 1:5-27

$>$ Hsieh YP, Chung SW, Tsau YJ, Sue CT (2002) Analysis of sulfide in the presence of ferric minerals by diffusion methods. Chem Geol 182:195-201

- Huerta-Diaz MA, Tessier A, Carignan R (1998) Geochemistry of trace metals associated with reduced sulfur in freshwater sediments. Appl Geochem 13:213-233

Huo WY, Li QS, Ma XN (2001) Study on acid volatile sulfide (AVS) of sediment in mariculture region of Jiaozhou Bay. Sci Geog Sin 21:135-139 (in Chinese with English Abstract)

Hyun J, Kim S, Mok J, Lee JS, An S, Lee WC, Jung R (2013) Impacts of long-line aquaculture of Pacific oysters (Crassostrea gigas) on sulfate reduction and diffusive nutrient flux in the coastal sediments of Jinhae-Tongyeong, Korea. Mar Pollut Bull 74:187-198

Jiang ZH, Ma QM, Wang XL, Zhang YY (2005) Study on the AVS in surface sediment in the north area of the Bohai Bay. Mar Environ Sci 24:6-8 (in Chinese with English Abstract)

Jiang ZJ, Wang GH, Fang JG (2012) Sediment resuspension mechanisms in aquaculture area, Sanggou Bay. J Environ Sci Eng A1:295-302

> Jørgensen BB (1978) A comparison of methods for the quantification of bacterial sulfate reduction in coastal marine sediments. Geomicrobiol J 1:29-47

> Jørgensen BB (1982) Mineralization of organic matter in the sea bed-the role of sulfate reduction. Nature 296: 643-645

Kang XM, Liu SM, Zhang GL (2014) Reduced inorganic sulfur in sediments of the Yellow and East China Seas. Acta Oceanol Sin 33:100-108

- Kraal P, Burton ED, Bush RT (2013) Iron monosulfide accumulation and pyrite formation in eutrophic estuarine sediments. Geochim Cosmochim Acta 122:75-88

> Lasorsa BM, Casas A (1996) A comparison of sample handling and analytical methods for determination of acid volatile sulfide in sediment. Mar Chem 52:211-220

Li JB, Zhang GL, Zhang J, Liu SM, Ren JL (2010) Matrix bound phosphine in sediments of the Yellow Sea and its coastal areas. Cont Shelf Res 30:743-751

> Lin S, Huang KM, Chen SK (2002) Sulfate reduction and iron sulfide mineral formation in the southern East China Sea continental slope sediment. Deep-Sea Res I 49: 1837-1852

- Liu SM, Li LW, Zhang ZN (2011) Inventory of nutrients in the Bohai. Cont Shelf Res 31:1790-1797

Lovley DR, Phillips EJP (1994) Novel process for anaerobic sulfate production from elemental sulfur by sulfatereducing bacteria. Appl Environ Microbiol 60:2394-2399

Lu J, Huang L, Luo Y, Xiao T, Jiang Z, Wu L (2015) Effects of freshwater input and mariculture (bivalves and macroalgae) on spatial distribution of nanoflagellates in Sungo Bay, China. Aquacult Environ Interact 6:191-203

Lückge A, Ercegovac M, Strauss H, Littke R (1999) Early diagenetic alteration of organic matter by sulfate reduction in quaternary sediments from the northeastern Arabian Sea. Mar Geol 158:1-13

> Martinez-Garcia E, Carlsson MS, Sanchez-Jerez P, SanchezLizaso JL, Sanz-Lazaro C, Holmer M (2015) Effect of sediment grain size and bioturbation on decomposition of organic matter from aquaculture. Biogeochemistry 125: 133-148

Ning Z, Liu S, Zhang G, Ning X and others (2016) Impacts of an integrated multi-trophic aquaculture system on benthic nutrient fluxes: a case study in Sanggou Bay, China. Aquacult Environ Interact 8:221-232

Otero XL, Calvo de Anta RM, Macías F (2006) Sulfur partitioning in sediments and biodeposits below mussel rafts in the Ría de Arousa (Galicia, NW Spain). Mar Environ Res 61:305-325

Pu XQ, Li F, Zhong SJ, Xu LJ (2008) Acid volatile sulfides in sediments of South Yellow Sea. Proc 2nd International Conference on Bioinformatics and Biomedical Engineering, 16-18 May 2008, Shanghai. Institute of Electrical and Electronics Engineers, Piscataway, NJ, p 1058-1061

Reid MK, Spencer KL (2009) Use of principal components analysis (PCA) on estuarine sediment datasets: the effect of data pre-treatment. Environ Pollut 157:2275-2281 
Santisteban JI, Mediavilla R, López-Pamo E, Dabrio CJ and others (2004) Loss on ignition: a qualitative or quantitative method for organic matter and carbonate mineral content in sediments? J Paleolimnol 32:287-299

Sanz-Lázaro C, Marin A (2006) Benthic recovery during open fish farming abatement in western Mediterranean, Spain. Mar Environ Res 62:374-387

Song XL, Yang Q, Sun Y, Yin H, Jiang SL (2012) Study of sedimentary section records of organic matter in Sanggou Bay over the last 200 years. Acta Oceanol Sin 34: 120-126 (in Chinese with English Abstract)

Sun S, Liu SM, Ren JL, Zhang JH, Jiang ZJ (2010) Distribution features of nutrients and flux across the sedimentwater interface in the Sanggou Bay. Acta Oceanol Sin 32: 108-117 (in Chinese with English Abstract)

Vismann B (1991) Sulfide tolerance: physiological mechanisms and ecological implications. Ophelia 34:1-27

Wei ZQ, Liu CQ, Liang XB, Wang FS, Wang SF (2005) Degradation of organic matter in the sediments of Hongfeng Reservoir. Chin Sci Bull 50:2377-2380

Xia DX (1991) The record of Chinese bays, Book Three

Editorial responsibility: Peter Cranford,

Dartmouth, Nova Scotia, Canada
(The northern and eastern bay of Shandong peninsula). Ocean Press, Beijing

Yokoyama H (2003) Environmental quality criteria for fish farms in Japan. Aquaculture 226:45-56

Zhang XL, Zhu MY, Chen S, Grant J, Martin JL (2006) Study on sediment oxygen consumption rate in the Sanggou Bay and Jiaozhou Bay. Adv Mar Sci 24:91-96 (in Chinese with English Abstract)

Zhang JH, Hansen PK, Fang JG, Wang W, Jiang ZJ (2009) Assessment of the local environment impact of intensive marine shellfish and seaweed farming-application of the MOM system in the in the Sungo Bay, China. Aquaculture 287:304-310

Zhu MX, Liu J, Yang GP, Li T, Yang RJ (2012) Reactive iron and its buffering capacity towards dissolved sulfide in sediments of Jiaozhou Bay, China. Mar Environ Res 80:46-55

> Zhu MX, Shi XN, Yang GP, Hao XC (2013) Formation and burial of pyrite and organic sulfur in mud sediments of the East China Sea inner shelf: constraints from solidphase sulfur speciation and stable sulfur isotope. Cont Shelf Res 54:24-36

Submitted: May 13, 2015; Accepted: October 13, 2015

Proofs received from author(s): November 9, 2015 